\title{
EHMTI-0361. Lack of differences in microrna expression profiles of blood cells in migraine
}

\author{
M Vila-Pueyo ${ }^{1 *}$, J Fernández-Morales ${ }^{1}$, M Torres-Ferrus $^{1}$, J Álvarez-Sabin², P Pozo-Rosich ${ }^{1}$ \\ From 4th European Headache and Migraine Trust International Congress: EHMTIC 2014 \\ Copenhagen, Denmark. 18-21 September 2014
}

\section{Introduction}

Migraine is a complex and very common neurological disorder. Several genome-wide significant loci have been described in migraine without explaining its whole genetic complexity. microRNAs are small non-coding RNAs involved in the regulation of gene expression that have become prominent candidates to explain the development of different neurological diseases and have also been described as key regulators in nociception.

\section{Aim}

To detect microRNA expression differences involved in the susceptibility and chronification of migraine.

\section{Methods}

20 migraineurs (5 episodic without aura, 5 chronic without aura, 5 episodic with aura, 5 chronic with aura) and 5 headache-free controls diagnosed by neurologists were included. In order to minimize differences, all 5 groups were homogenous regarding age (average $40.4 \pm 1.98$ ), sex (3 women, 2 men), and a family history of migraine (firstdegree relatives). Patients diagnosed with chronic migraine suffered from more than 15 days/month and patients diagnosed with episodic migraine had 1-2 days/month. Patients with aura suffered from more than $50 \%$ of attacks with aura.

RNA was extracted from peripheral blood mononuclear cells (PBMCs), microRNA expression profiles were determined and all possible comparisons were performed.

\section{Results}

There were no statistically significant differences in any of the comparisons performed.

${ }^{1}$ Headache and Neurological Pain Group, Vall Hebron Research Institute, Barcelona, Spain

Full list of author information is available at the end of the article

\section{Conclusions}

This is the first microRNA analysis performed in migraine. The negative results indicate the lack of differences in microRNA expression in PBMCs in migraine. However, gene expression regulatory mechanisms such as microRNAs are tissue and cell specific, suggesting that differences in microRNA expression linked to migraine should be explored in brain tissue.

No conflict of interest.

\section{Authors' details}

${ }^{1}$ Headache and Neurological Pain Group, Vall Hebron Research Institute, Barcelona, Spain. ${ }^{2}$ Neurology, Vall Hebron Hospital, Barcelona, Spain.

\section{Published: 18 September 2014}

doi:10.1186/1129-2377-15-S1-H3

Cite this article as: Vila-Pueyo et al:: EHMTI-0361. Lack of differences in microrna expression profiles of blood cells in migraine. The Journal of Headache and Pain 2014 15(Suppl 1):H3.

\section{SpringerOpen $^{\odot}$}

(c) 2014 Vila-Pueyo et al; licensee Springer. This is an Open Access article distributed under the terms of the Creative Commons Attribution License (http://creativecommons.org/licenses/by/2.0), which permits unrestricted use, distribution, and reproduction in any medium, provided the original work is properly cited.
Submit your manuscript to a SpringerOpen ${ }^{\circ}$ journal and benefit from:

- Convenient online submission

- Rigorous peer review

- Immediate publication on acceptance

- Open access: articles freely available online

- High visibility within the field

- Retaining the copyright to your article

Submit your next manuscript at $>$ springeropen.com 